ROBERT KUŚNIERZ* - SŁUPSK

\title{
STALINOWSKA KONSTYTUCJA Z 1936 ROKU I NADZIEJE WIERZĄCYCH NA SOWIECKIEJ UKRAINIE NA ZMIANE ANTYRELIGIJNEJ POLITYKI BOLSZEWIKÓW
}

Bolszewicy dokonując przewrotu zbrojnego zamierzali nie tylko przejąć władze w państwie, ale chcieli zmienić dotychczasowe stosunki społeczne, a z nimi obowiązujące wartości. Ich celem było stworzenie zupełnie innego systemu z „nowymi ludźmi sowieckimi”, którzy kierować się mieli „nowymi komunistycznymi wartościami”. W kanonie tych „wartości” nie było oczywiście miejsca ani dla religii chrześcijanskiej, ani dla żadnej innej. Komunizm bowiem miał być nie tylko systemem politycznym, miał również stać się swego rodzaju ,religią ateistyczną” opartą na wierze zbudowania „bolszewickiego raju” na ziemi ${ }^{1}$. Rosyjski filozof emigracyjny, Nikołaj Bierdiajew, przedstawił bardzo interesującą analizę stosunku komunizmu do religii:

Komunizm, nie jako system socjalny, ale jako religia, jest wrogi wszelkiej religii, a najbardziej [religii] chrześcijańskiej. Sam chce być religią, która zastąpi chrześcijaństwo, aspiruje do dawania odpowiedzi na pytania (zaprosy) duszy ludzkiej, do ukazania sensu życia. Komunizm jest kompleksowy (celostien),

\footnotetext{
* Robert Kuśnierz - dr hab. historii; prof. Akademii Pomorskiej w Słupsku; dyrektor Instytutu Historii i Politologii AP; email: robert.kusnierz@apsl.edu.pl

${ }^{1}$ R. Kuśnierz, W świecie stalinowskich zbrodni. Ukraina w latach czystek i terroru (1934-1938) w obserwacjach $i$ analizach MSZ oraz wywiadu wojskowego Drugiej Rzeczypospolitej, Słupsk 2013, s. 318-319. Jemelian Jarosławski, jeden z czołowych bolszewickich strategów do walki z religią, szef Związku Wojujących Bezbożników, w 1937 r. pisał w moskiewskiej „Prawdzie”: „Komuniści uznają religię za zło, przeciwko któremu walczą poprzez perswazję, poprzez propagandę (...). Komuniści poprzez swoją antyreligijną i kulturowo-oświatową propagandę, poprzez całą swą działalność cierpliwie pomagają pracującym pokonać przeżytek przeszłości, obcą naukowemu rozumieniu świata ideologię, zerwać z kłamliwymi, iluzorycznymi wierzeniami w życie pozagrobowe, w bogów, boginie, świętych, aniołów, diabłów, raj i piekło. Bolszewicy pomagają pracującym tutaj, na ziemi, zbudować radosne dla wszystkich, szczęśliwe życie”. Tamże, s. 319.
} 
obejmuje całe życie, nie odnosi się do jakiejkolwiek dziedziny społecznej.

Dlatego jego starcie się z innymi wierzeniami religijnymi jest nieuniknione ${ }^{2}$.

Tak samo zauważał ambasador Francji w Związku Sowieckim, François Alphand. 20 lipca 1934 r. w meldunku do Paryża oceniając kierunek sowieckiej polityki wyznaniowej napisał, że komuniści wprowadzają „,nową religię, naturalnie wykluczającą każdą inną"3.

Wzorowanie się bolszewizmu na chrześcijaństwie było bardzo wyraźne. Biblię zastapiły „święte księgi” komunizmu - dzieła Lenina, później Stalina. Każdy komunista musiał mieć pisma „,wodzów”. Zamiast opisów ewangelicznych, propagowano opisy męstwa i ,nadludzkiej mądrości” Władimira Lenina, który już jako dziecko (Wołodia Ulianow) miał takowymi się odznaczać. Portrety komunistycznych ,świętych” zastąpiły obrazy religijne i ikony. Pielgrzymki do miejsc świętych zostały zastąpione tymi do mauzoleum Lenina w Moskwie. W każdej miejscowości starano się tworzyć (zwłaszcza w szkołach) kąciki poświęcone Leninowi, gdzie znajdowały się jego pisma, kopie eksponatów z jego domu, zdjęcia etc. Pionierwożatyj opowiadał(a) w tych kącikach o ,bohaterskich czynach Lenina". Zamiast chrześcijańskiego Zmartwychwstania - nastąpiła deifikacja wodza bolszewików (Lenin wiecznie żywy). Zamiast Trójcy Św., była trójca komunistów - Marks, Engels, Lenin. Zamiast męczenników - byli sowieccy męczennicy w rodzaju Pawlika Morozowa i wielu jego naśladowców. Wiarę w życie pozagrobowe, zastąpiła wiara w ,bolszewicki raj” na ziemi, kiedy już zostanie zbudowany komunizm. W wielu przemówieniach czy artykułach prasowych, nawet samego Stalina, używano sformułowań biblijnych lub ich karykatur. „Prawda” pisząc o trzecim procesie moskwiewskim określała Trockiego Judaszem, pisząc, że jego imię jest przeklęte „na wieki wieków”. Stalin podczas plenum lutowo-marcowego w 1937 r., po którym rozpoczęła się czystka w szeregach NKWD, mówił o potrzebie wprowadzenia nowych, młodych ludzi do struktur partyjnych i państwowych. Skończył wywód: „Szukajcie, a znajdziecie”4.

Jeden z najbardziej znanych współczesnych pisarzy rosyjskich Władimir Makanin, również zauważył, że komunizm trzymał się dokładnie takich samych zasad, na których opierało się chrześcijaństwo:

Po pierwsze, byli prorocy - Karol Marks i Fryderyk Engels. Po drugie, był mesjasz w osobie Lenina, który rzeczywiście pokonał śmierć - ludzie byli przecież święcie przekonani, że on żyje tam, w trumnie, w mauzoleum. Po trzecie, wreszcie, był cały szereg świętych: na przykład Pawlik Morozow, który doniósł na ojca, a potem został zabity przez dziadka i wuja; była prawosławna męczennica Warwara, która również doniosła i również została zabita przez krewnych; męczennikiem był też spalony w palenisku parowozu Siergiej Łazo. Cały sowiecki ikonostas był zapełniony bohaterami, męczennikami i świętymi. Naród nie wielbił ich jednak dlatego, że był niedołężny i zmuszony powtarzać to, co mu kazano, ale dlatego, że rzeczywiście długo w to wie-

${ }^{2}$ N. Bierdiajew, Istoki i smyst russkogo kommunizma, Paris (Pariż) 1955, s. 129.

${ }^{3}$ Cyt. za: R. Dzwonkowski SAC, Sowieckie państwo wyznaniowe, „Roczniki Nauk Społecznych", 1 (1997) s. 298.

${ }^{4}$ R. Kuśnierz, Czystki i terror na Ukrainie (1934-1938), Toruń 2016, s. 98. 
rzył. Świadomość radziecka ukształtowała się według zasad analogicznych do świadomości religijnej. Chrześcijaństwo i komunizm - jak jeden do jednego! ${ }^{5}$

Z kolei historyk Kościoła katolickiego w ZSRS, ks. Roman Dzwonkowski SAC, zauważał, że państwo sowieckie, będące z zasady państwem ateistycznym, stało się de facto państwem par excellence wyznaniowym. Opierało się bowiem na obowiązującej wszystkich obywateli, którzy piastowali jakiekolwiek stanowiska państwowe, zasadzie oficjalnej wiary w nieistnienie Boga ${ }^{6}$.

Stąd już od samego początku przejęcia władzy, bolszewicy walczyli z religią. Przybierała ona różne formy. Na początku system dążył do ograniczenia praw związkom wyznaniowym jak i duchownym ${ }^{7}$. W 1929 r. wraz z rozpoczęciem kolektywizacji i industrializacji przystąpiono także do zmasowanego ataku na religię, którego celem miało być jej całkowite zniszczenie ${ }^{8}$. W 1930 r. na Ukrainie aresztowano połowę księży katolickich . W 1930 r. zlikwidowano Ukraińską Autokefaliczna Cerkiew Prawosławna ${ }^{10}$. Druga połowa lat trzydziestych XX w. to „dobijanie" religii ${ }^{11}$. W samym tylko obwodzie kijowskim do 20 marca $1937 \mathrm{r}$. zamknięto 1579 świątyń wszystkich wyznań, czynnych pozostało oficjalnie 311 (tab. 1). Jednak nie była to faktyczna liczba świątyń, do których wierni mogli wejść i uczestniczyć w nabożeństwach, ponieważ aż 90 z 273 funkcjonujących na papierze cerkwi zostało „użyczonych” na składy zboża. Przeznaczenie zamkniętych świątyń wyglądało w sposób następujący: 590 przebudowano na tzw. za-

\footnotetext{
${ }^{5}$ Kiedy Sparta wygrywa z Atenami, „Nowa Europa Wschodnia”, 1 (2014) s. 143.

${ }^{6}$ Dzwonkowski, Sowieckie państwo, s. 298; tenże, Kościól katolicki w ZSSR 1917-1939. Zarys historii, Lublin 1997, s. 68-69.

${ }^{7}$ Dekret Komisarzy Ludowych z 23 stycznia (według nowego stylu 2 lutego) 1918 r. O rozdziale cerkwi od państwa i szkoły od cerkwi pozbawiał duchowieństwo praw wyborczych (tzw. liszeńcy), zakazywał nauki religii do lat 18. W lutym 1922 r. uchwalono dekret, na mocy którego wszystkie „domy modlitwy” zobowiązane zostały do przekazania swoich rzeczy ze złota, srebra i kamieni szlachetnych na fundusz pomocy ofiarom głodu. Postanowienie z 8 kwietnia 1929 r. zakazywało organizacjom religijnym powoływania „towarzystw pomocy wzajemnej”, udzielania wsparcia materialnego swoim członkom, organizowania specjalnych zebrań modlitewnych dla dzieci, młodzieży, kobiet, otwierania bibliotek, czytelń, prowadzenia domów pomocy społecznej etc. Księżom i personelowi kościelnemu zakazano mieszkania w pobliżu kościołów i śródmieścia. W 1930 r. w związku z „brakiem papieru dla prasy codziennej” wydano rozporządzenie zobowiązujące osoby prywatne oraz „domy modlitwy” do oddawania władzom lokalnym Biblii, literatury religijnej i modlitewników. Zob.: Dzwonkowski, Kościót katolicki, s. 63, 66, 100; J. Wróbel, Polityka ZSRR wobec Kościoła katolickiego w latach 1917-1939, w: Polacy w Kościele katolickim w ZSRR, red. E. Walewander, Lublin 1989, s. 89; R. Conquest, Żnywa skorboty. Radiańska kotektywizacija i hotodomor, Kyjiw 1993, s. 228-230.

${ }^{8}$ Ważniejsze pozycje traktujące o walce z religią w ZSRS, zob. Kuśnierz, $W$ świecie stalinowskich zbrodni, s. 320 (przypis 7).

${ }^{9}$ R. Kuśnierz, Ukraina w latach kolektywizacji i Wielkiego Głodu (1929-1933), Toruń 2005, s. 241.

${ }^{10}$ Ważniejsze prace nt. UACP wymieniam w mojej monografii $W$ świecie stalinowskich zbrod$n i$, s. 321 (przypis 8).

${ }^{11}$ Tamże, s. 321.
} 
kłady kulturowe; 756 nie przebudowano, pozostawiając de facto na niechybne niszczenie; 247 przekształcono na składy zbożowe.

Tabela 1. Czynne świątynie w obwodzie kijowskim z rozbiciem na wyznania, stan na 20 marca $1937 \mathrm{r}$.

\begin{tabular}{|l|c|}
\hline Rodzaj świątyni & \multicolumn{1}{c|}{ Liczba czynnych świątyń } \\
\hline Cerkwie & $\begin{array}{r}273 \text { (90 cerkwi, choć oficjalnie nie zostały zamknięte, } \\
\text { zostały „użyczone” na składy zbożowe) }\end{array}$ \\
\hline Synagogi & 29 \\
\hline Kościoły & 5 \\
\hline Kaplice & 4 \\
\hline Łącznie & 311 \\
\hline
\end{tabular}

Źródło: CDAHOU, f. 1, op. 20, spr. 7105, ark. 2.

Podobnie wyglądała sytuacja w obwodzie winnickim. Z 2613 świątyń różnych odłamów chrześcijaństwa i judaizmu do 20 marca 1937 r. pozostało czynnych $439^{12}$. W innych regionach imperium sowieckiego sytuacja wylądała identycznie. Zamykano kościoły, aresztowano, mordowano lub deportowano księży, prześladowano wiernych.

Lata trzydzieste XX w. to najbardziej mroczny okres w dziejach stalinizmu. Oprócz walki z religią, reżim miał na sumieniu kilka milionów chłopów zagłodzonych w latach 1932-1933. Od zabójstwa Kirowa zaczęła się czystka w partii. W sierpniu $1936 \mathrm{r}$. odbył się pierwszy z trzech pokazowych procesów moskiewskich. Już od końca lat dwudziestych reżim organizował fikcyjne procesy sądowe, gdzie na ławach oskarżonych sadzano prawie zawsze niewinnych ludzi, tj. tych, którzy na pewno nie popełnili przestępstw politycznych, o które ich oskarżono. Preparowane były fikcyjne „kontrrewolucyjne organizacje antysowieckie”, jak np. tzw. Polska Organizacja Wojskowa, Narodowy Związek Niemców na Ukrainie etc. W takiej oto sytuacji 5 grudnia 1936 r. uchwalono w Związku Sowieckim konstytucję ${ }^{13}$.

Państwo sowieckie to państwo z dwoma rzeczywistościami - oficjalną widzianą tylko na papierze, w propagandowych filmach i przemówieniach dygnitarzy, a także rzeczywistością realną. Polski ambasador w Moskwie Wacław Grzybowski w liście do Józefa Becka z 8 lutego 1937 r. napisał: „Kontrast pomiędzy fikcyjną rzeczywistością rewolucji, a rzeczywistością codzienną jest uderzający"14. Słowa te celnie oddawały istnienie ,równoległych rzeczywistości” w państwie sowieckim. Konstytucja stalinowska była w tym kontekście typowym przykładem. Oficjalnie - najbardziej demokratyczna w świecie, w praktyce - nikt spe-

${ }^{12}$ Centralnyj Derżawnyj Archiw Hromadśkych Obiednań Ukrajiny u Kyjewi (dalej: CDAHOU), fond 1, opys 20, sprawa 7105, arkusz 1 .

13 Tekst konstytucji, zob. np.: http://www.hist.msu.ru/ER/Etext/cnst1936.htm, (dostęp: 6.6.2015). Omówienie ważniejszych założeń, zob. A. Lityński, Prawo Rosji i ZSRR 1917-1991 czyli historia wszechzwiązkowego komunistycznego prawa (bolszewików). Krótki kurs, Warszawa 2010, s. $66-83$.

${ }^{14}$ Kuśnierz, $W$ świecie stalinowskich zbrodni, s. 344. 
cjalnie nie przejmował się jej zapisami. Zapisy o rozmaitych wolnościach były skierowane raczej do zagranicy $\mathrm{w}$ celach propagandowych ${ }^{15}$. Biorąc pod uwage sowieckie realia lat 30 . XX w., zapisy artykułu 125 konstytucji brzmią jako wręcz gorzki żart. Otóż każdemu obywatelowi zagwarantowano swobodę słowa, druku, zgromadzeń, ulicznych pochodów i manifestacji. Równie obłudne zapisy znalazły się w artykule 124, który jest kluczowy dla niniejszego artykułu:

W celu zapewnienia obywatelom swobody sumienia, cerkiew w ZSRS jest oddzielona od państwa i szkoła od cerkwi. Każdy obywatel ma prawo do odprawiania kultu religinego i prawo do antyreligijnej propagandy.

Artykuł ten jak widzimy w teorii gwarantował każdemu obywatelowi wolność wyznania i prawo do celebry i udziału w nabożeństwach religijnych. Co prawda swobody demokratyczne wynikające $\mathrm{z}$ konstytucji traktowano w społeczeństwie sowieckim $\mathrm{w}$ większości jako kolejny przejaw nierealnej rzeczywistości propagandowej ${ }^{16}$, to jednak pewnym wyjątkiem był zapis artykułu 124 . $\mathrm{W}$ dość krótkim czasie z różnych zakątków Związku Sowieckiego zaczęły płynąc sygnały o nadziejach społeczeństwa na zmianę dotychczasowej wyznaniowej polityki bolszewików. Doszło nawet do tego, że wierni władzom czynni popi (w większości tylko oni sprawowali swoje urzędy) zaczęli wychwalać nową ustawę zasadniczą wygłaszając czasami wręcz absurdalne tezy. Protojerej O. Pospiełow, a za nim inni duchowni twierdzili, że władza sowiecka, rzekomo mająca oparcie w narodzie, była nie tylko władzą legalną, ale i władzą ustanowioną przez

${ }^{15}$ Papież Pius XI odnosząc się do projektu konstytucji powiedział w rozmowie z hr. Bogdanem Hutten-Czapskim, że projekty konstytucji to ,jedno wielkie oszustwo” dziwiąc się, że „można znaleźć ludzi, którzy by to brali na serio". M. Kornat, Papież Pius XI i Polska w dobie totalitaryzmów i kryzysu systemu wersalskiego (1933-1939), „Studia nad Faszyzmem i Zbrodniami Hitlerowskimi”, 30 (2008) s. 198. Jednak kłamstwa nie tylko o konstytucji, ale i innych „sowieckich zdobyczach” trafiały często na podatny grunt na Zachodzie. Bardzo dobrą analizę tego aspektu przeprowadził Dariusz Tołczyk w swojej książce Gułag w oczach Zachodu, Warszawa 2009. Nie miały żadnych wątpliwości co do istoty bolszewickiego przedsięwzięcia polska służba zagraniczna i wywiad. Zob. Kuśnierz, $W$ świecie stalinowskich zbrodni, s. 359-360.

${ }^{16}$ We wrześniu 1936 r., a więc jeszcze przed zatwierdzeniem nowej konstytucji, kierownik polskiej placówki wywiadowczej E.10, Stanislaw Suchecki, informował centralę wywiadu w Warszawie, że zainteresowanie ogółu społeczeństwa konstytucją było słabe, ludzie nie wierzyli w większe swobody. Suchecki w rozmowach z napotkanymi ludźmi prowokując ich mówił, że projekt konstytucji daje możliwości do organizowania się i wypowiadania. Odpowiadano mu, że nie zna stosunków rosyjskich, więc nie wie, że w Rosji „nie było nigdy swobody i nie będzie, dopóki ktoś obcy nie zrobi porządku”. Według obserwacji Sucheckiego tylko wśród inteligencji dało się zaobserwować nadzieję na lepsze warunki życia. Zob. Rossijskij Gosudarstwiennyj Wojennyj Archiw w Moskwie, fond $308 \mathrm{k}$, opiś 19 , dieło 63 , list 188 . NKWD również niejednokrotnie odnotowywało prawdziwe podejście społeczeństwa do zapisów ustawy zasadniczej. Wszelkie takie przejawy były traktowane jako „wrogie działania”. Np. we wsi Radulino rejonu baranowskiego Charyton Chomecza mówił w związku z prowadzonymi aresztowaniami: „Zabierają ludzi, ktorych się boją, jednak już niedługo przyjdzie czas, kiedy ich będą brali. Konstytucja swoje, a rzeczywistość swoje. Konstytucja daje każdemu prawo do wiary, a powiedz cokolwiek, od razu zabiorą do NKWD”. S. Żyluk, Czerwonyj teror proty duchowenstwa i wirujuczych na Schidnij Wolyni (Żytomyrszczyna) u 20-30-ch rokach XX st. Archiwni dokumenty ta materiaty, Riwne 2003, s. 92. 
Boga (sic!), a „wyniki sowieckiego ustroju były wskaźnikiem Bożej łaski dla niego". W miejscowości Dobrianka w obwodzie czernihowskim pop wzywał ludność do modłów dziękczynnych ,za ofiarowanie nowej konstytucji dla ZSRS" ${ }^{17}$. W różnych częściach Związku Sowieckiego miały miejsce przypadki, kiedy duchowni pisali listy do Stalina gloryfikując ,nieśmiertelny dokument historyczny - stalinowską konstytucję". Inni stużytieli kulta ${ }^{18}$ deklarowali propagowanie konstytucji $\mathrm{z}$ ambon czy urządzali modły dziękczynne za artykuł $124^{19}$.

Księża, którzy zostali pozbawieni swoich parafii i urzędów, jeżeli nie zostali pozbawieni wolności, starali się zmobilizować wiernych do działań mających na celu otwarcie zamkniętych poprzednio świątyń i przywrócenie stanowisk usuniętym w związku z zamknięciem świątyń, kapłanom. Ludzie, na początku z ostrożnością, później coraz śmielej, zaczęli interpretować artykuł 124 literalnie - myśląc, że komuniści zaprzestaną represji wobec księży i wiernych, zaczęli domagać się zwrotu zabranych świątyń i przysłania kapłanów. Tylko w ciągu czterech dni, od 29 marca do 1 kwietnia 1937 roku wpłynęło na całej Ukrainie 270 podań z prośbami o otwarcie świątyń ${ }^{20}$. W kwietniu 1937 roku w tym celu do Wszechukraińskiego Centralnego Komitetu Wykonawczego przybyło aż 95 delegacji z kijowskiego oraz 119 z innych obwodów reprezentujące różne wspólnoty religijne $^{21}$. Starosta cerkiewny w mieście Latyczów w obwodzie winnickim, Słomiński, zebrał w 11 miejscowościach 635 podpisów (w tym od wielu pionierów) w sprawie otwarcia cerkwi ${ }^{22}$. We wsi Nowa Petriwka koło Kijowa w kwietniu 1937 roku przed Wielkanocą, cerkowniki ${ }^{23}$ zebrali 1200 podpisów za otwarciem cerkwi. Oprócz tego zebrano środki pieniężne na wystrój świątyni ${ }^{24}$. W Nowogradzie Wołyńskim grupa wiernych pod przewodnictwem wiekowego ks. Aleksandra Bartałowicza prowadziła zbiórkę pieniędzy na zakup domu, który miała zaadaptować na świątynię. Członkowie grupy zbierali podpisy z petycją do władz o wyrażenie na to zgody. We wsi Sujimci w rejonie nowograd-wołyńskim pop Baranowicz po opublikowaniu konstytucji zwołał zebranie parafian, na którym nawoływał ludzi do zbierania podpisów za otwarciem cerkwi. We wsiach tego samego rejonu Nesołoń i Tupolci zebrano 500 podpisów ${ }^{25}$. We wsi Toporzyszcze na Żytomierszczyźnie przyjezdny pop wyjaśniał ludziom znaczenie artykułu 124

${ }^{17}$ Kuśnierz, $W$ świecie stalinowskich zbrodni, s. 336.

${ }^{18}$ Stużytiel kulta, czyli duchowny.

${ }^{19}$ K. Petrone, Life Has Become More Joyous, Comrades: Celebrations in the Time of Stalin, Bloomington-Indianapolis 2000, s. 186.

${ }^{20}$ CDAHOU, f. 1, op. 20, spr. 7105, ark. 2.

${ }^{21}$ N. Rublowa, Represiji proty ,, cerkownykiw” $i$,, sektantiw” w URSR, 1917-1939 rr., ,Z Archiwiw WUCzK-GPU-NKWD-KGB”, 1 (2007) s. 214.

${ }^{22}$ CDAHOU, f. 1, op. 20, spr. 7105, ark. 9.

${ }^{23}$ Dosł. ludzie cerkwi. W sowieckich dokumentach określało się tak wszystkich aktywnych wiernych świeckich, a czasami także duchownych. Przy czym, według bolszewików, żeby zostać „aktywnym cerkownikiem” wystarczyło regularnie uczęszczać na nabożeństwa lub nie zgadzać się, nawet słownie, z polityką władz wobec religii (np. zamykanie świątyń).

${ }^{24}$ Tamże, ark. 14.

${ }^{25}$ Żyluk, Czerwonyj teror, s. 92-93. 
stalinowskiej konstytucji, który według niego zapewniał nieskrępowane prawo do propagandy religijnej. Pop organizował chrzty dzieci twierdząc, że teraz nawet komuniści będą chrzcili swoje potomstwo. Duchowny był w swojej argumentacji bardzo skuteczny, bowiem kandydat do członkostwa w partii Szymon ochrzcił swoje dziecko. Za ten czyn komunista został zdegradowany do rangi sympatyka ${ }^{26}$. Było wiele przypadków, o których donosiła nawet sowiecka prasa, kiedy komsomolcy i komuniści brali śluby w cerkwiach i chrzcili dzieci ${ }^{27}$, śpiewali w chórach prowadzonych przez duchownych, byli członkami rad parafialnych, uczęszczali na zebrania, gdzie czytano kołchoźnikom Biblię - i jak z oburzeniem napisała „Prawda” - nie widzieli w tym nic nagannego ${ }^{28}$.

Prokurator generalny USRS Hryhorij Żeleznogorski informował drugiego sekretarza KC KP(b)U Mendela Chatajewicza 5 maja 1937 roku, że okres pomiędzy drugą połową 1936 roku a początkiem 1937 roku odznaczał się znaczącym nasileniem się religijnej i ,antysowieckiej kontrrewolucyjnej propagandy”. Podstawą ku temu był wspomniany artykuł 124 stalinowskiej konstytucji, który zapewniał wolność swobody religijnej jak i propagandy antyreligijnej. Wiele osób podpierając się tym zapisem zwracało się do władz o jego wykonanie. Prowadzono nielegalne zbiórki pieniędzy na rzecz cerkwi i inne religijne potrzeby.

Żeleznogorski pisał, że religijna działalność ożywiła się zwłaszcza w obwodach winnickim, czernihowskim i charkowkim. Co nie oznacza, że w innych obwodach ludzie nie interesowali się życiem religijnym. Tej propagandzie sprzyjał fakt, iż wiele cerkwi było, co prawda, fizycznie zamkniętych, ale brakowało wymaganego potwierdzenia przez CKW USRS. Tylko w obwodzie czernihowskim ze 1058 nieczynnych cerkwi, CKW USRS nie zatwierdził zamknięcia 200 z nich $^{29}$.

W obwodach winnickim, czernihowskim i charkowskim zarejestrowano fakty rozpowszechniania ulotek. Jedna z nich głosiła, że każdy, kto ją otrzymał, powinien przekazać dalej w dziewięciu egzemplarzach, wykorzystując do tych czynności uczniów ${ }^{30}$. We wsi Mikłasze w obwodzie winnickim 22 kwietnia 1937 roku podczas pobytu w szkole u 14-letniej uczennicy Wiry Baran znaleziono ulotkę o następującej treści:

Od 22 kwietnia do 1 maja spalona zostanie szkoła, chata przewodniczącego rady wiejskiej oraz przewodniczącego kołchozu. Kto znajdzie tę ulotkę, uprasza się o odniesienie jej do rady wiejskiej. Póki nie oddadzą cerkwi, dopóty będziemy palić.

Wira Baran przyznała się, że sama to napisała pod wpływem mieszkanki wsi Miklase o nazwisku P. Maciuk, która była aktywistką cerkiewną ${ }^{31}$.

$\mathrm{Na}$ Donbasie miało miejsce wiele przypadków pojawienia się na bazarach lub innych zatłoczonych miejscach (Makijówka, Mariupol, Stalino, Kadijówka) starców i krzykaczek (krikuszy), którzy podawali się za Jezusa Chrystusa, św. Pawła

\footnotetext{
${ }^{26}$ Tamże, s. 99.

${ }^{27}$ A. Kosariew, Antirieligioznaja propaganda i zadaczi komsomoła, „Prawda” z 15 IV 1937 r.

${ }^{28}$ Antirieligioznaja propaganda, „Prawda” z 7 V 1937 r.

${ }^{29}$ CDAHOU, f. 1 , op. 20 , spr. 7105 , ark. 5.

${ }^{30}$ Tamże, ark. 6.

${ }^{31}$ Tamże, ark. 9.
} 
i innych świętych. Zbierali środki wśród wiernych zachęcając ich do występowania do władz o otwarcie zamkniętych cerkwi ${ }^{32}$.

Dochodziło do buntów (tzw. wołynki). W 1936 roku na Czernihowszczyźnie miało miejsce dziewięć wołynek, których przyczyna leżała w walce o otwarcie cerkwi. W rejonie kriukowskim w obwodzie czernihowskim były szef rejonowego komitetu wykonawczego Szum zamknął bez ,jakiejkolwiek pracy przygotowawczej" 17 cerkwi w ośmiu wsiach bez pozwolenia obwodowego komitetu wykonawczego, co spowodowało bunt ludności miejscowej. W tym obwodzie aresztowano za ,aktywną działalność kontrrewolucyjną” 148 osób ${ }^{33}$.

Podobny raport opracowało również ukraińskie NKWD w dniu 25 kwietnia $1937 \mathrm{roku}^{34}$. W nim zwracano uwagę na dużą liczbę ,nielegalnych” chrztów udzielanych przez popów w mieszkaniach. W domach prywatnych, w związku z pozamykaniem świątyń, odbywały się $\mathrm{w}$ obecności księży także inne uroczystości religijne. W rejonie wyskowskim pop Siemionow i diak Witwicki organizowali w mieszkaniu cerkowniczki Sanko trzydniowe modły. Kiedy przewodniczący sielsowietu kazał zakończyć „,bezprawne zgromadzenia”, Semionow oświadczył:

Teraz działamy w oparciu o nową konstytucję. Nikogo się nie boimy, nie potrzebujemy żadnych pozwoleń. Jeśli tego nie wiesz, to przeczytaj lepiej nową konstytucję.

W rejonie troickim aktywiści cerkiewni agitowali wśród społeczeństwa twierdząc:

Mamy jednak rację. Władza sowiecka wkracza na drogę otwierania cerkwi. Jednak Boga się boi. Sam Stalin widzi, że jeżeli nie zmuszać chłopa do modlitwy do Boga, to chleba cały czas nie będzie. Konstytucja jest za nami i życie powróci do starych [tradycji].

W rejonie wozniesieńskim popi Wengerenko, Sandułenko i Suworiew chrzcili masowo dzieci w wieku szkolnym i zachęcali do regularnego chodzenia do cerkwi i niewstępowania do szeregów pionierów. Agitując za udzielaniem chrztów, nierzadko twierdzili, że gdy przyjdzie Hitler na Ukrainę wszystkie nieochrzczone dzieci zostaną zlikwidowane.

Do wzmocnienia aktywności cerkownikow przyczynić się miała nawet gazeta walcząca z „przesądem religijnym” „Bezbożnyk” (Bezbożnik). 27 lipca 1937 roku niejaki Osadczy napisał do Kosiora donos w sprawie „kontrrewolucyjnych treści” w numerze z 5 lipca 1937 roku. Gazeta ta napisała m.in.: „Ostatnimi czasy, szczególnie po zatwierdzeniu stalinowskiej konstytucji, cerkowniki wszczynają aktywną propagandę religijną, organizują zgromadzenia religijne [...]”. Według autora donosu publikując taką informację, gazeta wzmacniała popów i podsuwała im konkretny program działania - organizujcie religijne wspólnoty. Kolejną podpowiedzią dla „elementu cerkiewnego" przepchniętą na łamach gazety miał być fragment wyjaśniający jak uniknąć nieporozumień podczas organizowania wspólnot religijnych: „Kiedy pracujący-wierzący chcą powołać wspólnotę i zaprosić

${ }^{32}$ Tamże, ark. 6.

${ }^{33}$ Tamże, ark. 7-8.

${ }^{34}$ Wetykyj teror w Ukrajini. „Kurkulśka operacija“ 1937-1938, cz. II, uporiadnyky S. Kokin, M. Junge, Kyjiw 2010, s. 449-455. 
do siebie popa, to jest to ich prywatna sprawa”. Pop mógł pracować tylko w tej wspólnocie - to kolejna instrukcja, według Osadczego, dla „wrogiego elementu”. W podsumowaniu donosiciel napisał, że różnica pomiędzy gazetą, która nazywa się „Bezbożnik” a dawnym organem cerkiewnym „Eparchijalnyje Wiedomosti” była bardzo mała, stąd postulował pociągnąc do odpowiedzialności redaktora naczelnego Hryhoriewa ${ }^{35}$.

Na fali rzekomej „odwilży religijnej”, również postanowił zainterweniować u władz były arcybiskup UACP Wołodymyr Samborski. Mieszkający wtedy w Białej Cerkwi były hierarcha napisał 20 stycznia 1937 roku do WUCKW pismo, w którym na początku wyrażał wdzięczność władzy sowieckiej za to, że w ciągu ostatnich 15 lat miał okazję być osobą duchowną odprawiającą nabożeństwa w języku ojczystym i podkreślał, że zawsze przejawiał wrogi stosunek do nacjonalistycznego szowinizmu. Następnie przeszedł do meritum. Powołując się na osławiony artykuł 124 stalinowskiej konstytucji, napisał, że przewiduje on, iż w ZSRS mogą być ludzie wierzący oraz kapłani (stużytieli kulta). Podkreślił, że nadal czuł się stużytielem kulta i wyrażał chęć kontynuowania swojej posługi $\mathrm{w}$ cerkwi prawosławnej $\mathrm{w}$ języku ukraińskim. W związku z tym $\mathrm{w}$ oparciu o wspomniany artykuł stalinowskiej konstytucji oraz artykuł 130 projektu konstytucji USRS prosił o ponowne wyrażenie zgody na odnowienie działalności Ukraińskiej Cerkwi Prawosławnej, która miałaby funkcjonować wyłącznie w ramach przepisów prawa obowiązujących w Związku Sowieckim. Jej zadaniem byłoby wyłącznie odprawianie nabożeństw w języku ukraińskim i miała ona wrogo odnosić się do wszelkich przejawów ukraińskiego nacjonalizmu i szowinizmu.

Oprócz tego, Samborski prosił w następnych punktach, aby powierzyć jemu organizację Ukraińskiej Cerkwi Prawosławnej oraz zorganizowanie soboru, który miał wybrać metropolitę. Hierarcha prosił o przydzielenie budynku dla swojej przyszłej cerkwi w Kijowie, a przed tym jak miało to nastąpić, upraszał o budynek dla swojej obecnej parafii w Białej Cerkwi, ponieważ od 1 grudnia 1934 roku nie dysponował świątynią ${ }^{36}$. W tym samym dniu abp Samborski pozwolił sobie również zaproponować pewne sugestie w stosunku do instrukcji kultu. Napisał, że przy „obecnie obowiązujących przepisach, w myśl których, jak nie ma świątyni, to nie ma parafii”, w ten sposób ignoruje się fakt istnienia wspólnoty wierzących, którzy mogliby spotykać się na modłach w prywatnych mieszkaniach. Ten właśnie aspekt arcybiskup proponował uwzględnić w instrukcjach kultu. Zwracał uwagę na inne problemy, np. na uregulowania kwestii zatrudnienia księży. Zgodnie z konstytucją każdy obywatel ZSRS miał przecież prawo do pracy ${ }^{37}$.

Władze bolszewickie całkowicie zignorowały postulaty Samborskiego, którego kilka miesięcy później - w czerwcu - aresztowano, a w październiku 1937 roku rozstrzelano, inkryminując jemu jak i pozostałym jeszcze żyjącym liderom byłej UACP przynależność do tzw. „Antysowieckiej Faszystowskiej Organizacji

\footnotetext{
${ }^{35}$ CDAHOU, f. 1 , op. 20 , spr. 7105 , ark. 21-22.

${ }^{36}$ Tamże, ark. 32-33.

${ }^{37}$ Tamże, ark. 34.
} 
Ukraińskich Cerkownikow" ${ }^{38}$. NKWD USRS w związku ze zbliżającymi się wyborami do Rad Najwyższych ZSRS i USRS kilkakrotnie w swoich instrukcjach (8 czerwca, 19 sierpnia, 5 października 1937 roku) dla lokalnych struktur, podkreślając ożywioną działalność duchowieństwa, żądało podjęcia zdecydowanych kroków w celu „rozgromienia cerkiewno-sekciarskich kadr kontrrewolucyjnych”39.

Odwilż pomimo tego, iż zmobilizowała wiernych do upominania się o swoje zamknięte świątynie, nie przyniosła jakiejś poprawy w życiu religijnym. Wskazują to choćby dane przytoczone na początku tego artykułu odnośnie do zamkniętych świątyń. Zbierając podpisy pod petycjami do władz, ludzie naiwnie wierzyli w zmianię postawy komunistów lub zapominali, że mają do czynienia z bolszewikami, którzy, co prawda, uchwalili najbardziej demokratyczną konstytucję na świecie, jednak interpretowanie zawartych w niej swobód pozostawiali samym sobie. Tutaj można przytoczyć zdarzenie, co prawda nie odnoszące się akurat do artykułu 124, ale dobitnie wskazujące jak enkawudziści traktowali zapisy stalinowskiej konstytucji. Więzień UNKWD w Winnicy A. Kożuszek 26 sierpnia 1940 roku zeznawał, że śledczy brutalnie znęcali się nad nim, kiedy ten przebywał w więzieniu. Pewnego razu maltretowany oświadczył swojemu oprawcy, śledczemu Antonowowi, że w państwie, gdzie obowiązuje stalinowska konstytucja, nie mają prawa prowadzić śledztwa takimi metodami. W odpowiedzi Antonow zaczął go bić, wykrzykując: „Masz tu konstytucję, masz tu prawo"

Jednak duch liberalizmu religijnego płynący, bądź co bądź, ze stalinowskiej konstytucji, wpłynął zapewne na większą frekwencję wiernych do jeszcze nie zamkniętych świątyń. Jak wynika z danych sowieckich, jak i choćby z obserwacji polskich konsulów, pomimo represji wobec duchowieństwa, jak i personelu pomocniczego, do momentu prowadzenia masowych operacji narodowościowych,

${ }^{38} \mathrm{~W}$ połowie $1937 \mathrm{r}$. przeprowadzono aresztowania byłych hierarchów i księży UACP - m.in. abpa Wołodymyra Samborskiego, abpa Jurija Michnowskiego i abpa Mykołę Karabijewycza. Od nich wydobyto zeznania, że istniała „Ukraińska Faszystowska Organizacja Cerkownikow”, do której należeli jakoby byli hierarchowie i księża UACP. Polecenie stworzenia nielegalnej siatki miał wydać pierwszy metropolita Wasyl Łypkiwski. Do tej organizacji NKWD także włączyło duchownych innych odłamów prawosławia. W czerwcu 1937 r. został aresztowany abp wołyński i żytomierski ukraińskiego egzarchatu Rosyjskiej Cerkwi Prawosławnej, Filaret (właśc. Andrej Linczewski). Zeznał, że organizacja działała w różnych częściach ZSRS, a na jej czele stał metropolita Sergiusz. Welykyj teror w Ukrajini. „,Kurkulśka operacija”, cz. I, s. 137. 20 listopada 1937 r. były metropolita Łypkiwski został skazany na śmierć. Stracono go 27 listopada 1937 r. o północy. Jego los podzielili inni uznani za członków „organizacji faszystowskiej” byli metropolici (Iwan Pawłowski oraz zmarły w łagrze Mykoła Borecki), biskupi, księża i świeccy UACP - zarówno przebywający na wolności, jak i odsiadujący poprzednie wyroki, np. skazany na 10 lat pozbawienia wolności w procesie Związku Wyzwolenia Ukrainy Wołodymyr Czechiwski. Został stracony 3 listopada 1937 r. po wyroku „trójki” obwodu leningradzkiego. CDAHOU, f. 263, op. 1, spr. 65685, t. 1, ark. 87-91. Notki i informacje o aresztowanych hierarchach i księżach UACP, zob.: Biohraficzni dowidky na mytropołytiw, jepyskopiw ta swiaszczennykiw UAPC, jaki zhadujut sia u dokumentach, „Z Archiwiw WCzK-GPU-NKWD-KGB”, 1-2 (2006) s. 311-328.

${ }^{39}$ Wetykyj teror w Ukrajini. „, Kurkulśka operacija“, cz. I, s. 148.

${ }^{40}$ O. Łoszyćkyj, ,Łaboratorija”. Nowi dokumenty $i$ swidczennia pro masowi represiji 19371938 rokiw na Winnyczyni, „Z Archiwiw WUCzK-GPU-NKWD-KGB”, 1-2 (1998) s. 201-202. 
miał miejsce napływ wiernych na nabożeństwa kościelne, zwłaszcza na Prawobrzeżnej Ukrainie ${ }^{41}$. Pomimo ciągłej propagandy antyreligijnej czynne kijowskie świątynie podlegające ,tichonowskiej” i „synodalnej” cerkwiom odwiedziło podczas świąt wielkanocnych w 1937 roku prawie 14.000 wiernych. W maju 1937 roku w Kijowie odbyło się w tych cerkwiach 549 chrztów ${ }^{42}$.

Konstytucja w żaden sposób nie zmieniła sytuacji mieszkańców Związku Sowieckiego, w tym Ukrainy. Jak już podkreślono, była tylko jednym z elementów fikcyjnej rzeczywistości sowieckiej. Jeżeli chodzi o walkę z religią, nie tylko jej nie zaprzestano, ale pomimo zapisów konstytucji, nasilono. Do końca lat 30. XX w. na Ukrainie zamknięto wszystkie kościoły katolickie oraz większość cerkwi. Do końca października 1937 roku trójki obwodowe NKWD skazały 2341 cerkowników, z czego na śmierć 1262. Skazano również 1128 ,sekciarzy” (ros. siektanty) ${ }^{43}$, z czego na karę śmierci $400^{44}$.

W dwóch ostatnich miesiącach 1937 roku nastąpiło znaczne zwiększenie liczby skazanych. NKWD USRS 5 października 1937 roku zwracało uwagę lokalnym ekspozyturom żeby „w jak najkrótszym terminie przeprowadziły szeroko zakrojoną operację $\mathrm{w}$ celu zdecydowanego rozgromienia cerkiewno-sekciarskich kadr kontrrewolucyjnych" ${ }^{45}$. Na efekty nie trzeba było długo czekać. Do 4 stycznia 1938 roku obwodowe trójki NKWD skazały łącznie 6368 duchownych i świeckich (cerkowniki) i sektantów, wśród skazanych było 3855 Niemców i 1818 Polaków ${ }^{46}$. W pierwszej połowie 1938 roku aresztowano 1474 osoby określone przez NKWD jako stużytieli kulta. W tym okresie skazano 1129 osób, z czego 954 na śmierćc7.

${ }^{41}$ Szerzej o tym, zob. Kuśnierz, $W$ świecie stalinowskich zbrodni, s. 340-343. Konsulat generalny RP w Kijowie podkreślał, że wielką skuteczność w dziedzinie przyciągania ludzi do kościoła wykazał ks. Zygmunt Kwaśniewski. W niedziele i święta liczba wiernych uczestniczących we mszach św. dochodziła do 2.000. Rezurekcja w 1937 r. w kościele św. Mikołaja ściągnęła do świątyni ok. 4000-5000 wiernych. Ludzie nie byli w stanie się zmieścić wewnątrz kościoła, musieli stać na schodach. W niedziele i święta każdorazowo odbywało się od 30 do 50 chrztów. W zwykły dzień chrztów było około 10. Również wiele było ślubów udzielanych w dwóch kijowskich parafiach rzymskokatolickich. Ludzie przyjmujący sakrament chrztu czy małżeństwa przybywali do Kijowa nie tylko z okolicznych miasteczek i wsi, ale i z daleka - Odessy, Szepetówki, Kamieńca Podolskiego, Połtawy. Dużą popularnością cieszyły się nabożeństwa majowe, na których gromadziło się 700-1000 osób. Enkawudziści wszelkimi metodami próbowali niedopuścić do rozwijania życia religijnego parafii katolickich w Kijowie. W maju 1937 r. zabroniono np. gry na organach w kościele św. Aleksandra, fotografowano ludzi uczęszczających na nabożeństwa. W końcu w nocy z 2 na 3 czerwca aresztowano księdza, a później inne osoby związane z funkcjonowaniem parafii. We wrześniu 1937 r. ks. Kwaśniewski został rozstrzelany.

${ }^{42}$ Rublowa, Represiji proty, s. 214.

${ }^{43}$ Sektantami byli dla komunistów wszyscy członkowie niezhierarchizowanych wyznań.

${ }^{44}$ Hałuzewyj Derżawnyj Archiw Słuzby Bezpeky Ukrajiny (dalej: HDASBU), f. 42, spr. 32, ark. 43. Zob. także: O. Bażan, Represiji sered duchowenstwa ta wirujuczych $w$ URSR $w$ czasy ,wetykoho teroru”: statystycznyj aspekt, „Z Archiwiw WUCzK-GPU-NKWD-KGB”, 2 (2007) s. 14; Kuśnierz, $W$ świecie stalinowskich zbrodni, s. 321-322.

${ }^{45}$ W. Paszczenko, A. Kyrydon, Bilszowyćka derżawa i prawosławna cerkwa w Ukrajini, $1917-$ 1930-ti roky, Połtawa 2004, s. 276.

${ }^{46}$ HDASBU, f. 42, spr. 33, ark. 39.

${ }^{47}$ Tamże, spr. 35, ark. 13-14, 17. 
Na koniec trzeba podkreślić, iż pomimo ciągłej walki z religią, społeczeństwo, zwłaszcza na wsi, pozostawało wierne swoim przekonaniom. Zgodnie z danymi ze spisu powszechnego z 1937 roku $^{48}$ większość mieszkańców ZSRS, a w miejscowościach wiejskich aż $2 / 3$, zadeklarowała, że jest wierząca ${ }^{49}$. Konsulat generalny RP w Kijowie podkreślał, w oparciu o własne obserwacje odnośnie do liczby uczęszczających na nabożeństwa, że pomimo ciągłej walki z religią „ludność lgnęła do Boga". Zwłaszcza dotyczyło to ludności wiejskiej. Najbardziej widocznym przejawem religijności było choćby to, że ludność w większości starała się świętować niedziele i święta, a pracowała w dni wolne ustanawiane przez władze $^{50}$. Olbrzymie wysiłki ateizacji i niszczenia fizycznego księży, wiernych, likwidowania świątyń wraz z kampanią propagandową szkalującą i wyśmiewającą religię, podejmowane przez reżim, nie były więc pod tym względem zbytnio udane.

Słowa kluczowe: stalinowska konstytucja; Sowiecka Ukraina; represje stalinowskie

\section{BIBLIOGRAFIA}

\section{Źródla}

Rossijskij Gosudarstwiennyj Wojennyj Archiw w Moskwie fond 308 k: II-j otdieł Gienieralnogo Sztaba Polszy, g. Warszawa

Centralnyj Derżawnyj Archiw Hromadśkych Obiednań Ukrajiny u Kyjewi fond 1: Centralnyj Komitet Kompartii Ukrajiny, 1917-1991.

Hałuzewyj Derżawnyj Archiw Służby Bezpeky Ukrajiny u Kyjewi fond 42: Operatywno-statystyczna zwitnist'

Wełykyj teror w Ukrajini. „Kurkulśka operacija” 1937-1938, uporiadnyky Serhij Kokin, Marc Junge, cz. I-II, Kyjiw 2010.

\section{Opracowania}

Bażan Ołeh, Represiji sered duchowenstwa ta wirujuczych w URSR w czasy „wełykoho teroru”: statystycznyj aspekt, „Z Archiwiw WUCzK-GPU-NKWD-KGB”, 2 (2007) nr 2, s. 7-18.

Bierdiajew Nikołaj, Istoki i smysł russkogo kommunizma, Paris (Pariż) 1955.

${ }^{48}$ Spis ten został utajniony, gdyż wykazał zbyt dużą „lukę” w liczbie ludności spowodowanej sztucznym głodem z lat 1932-1933 r.

${ }^{49}$ Rublowa, Represiji proty, s. 213.

${ }^{50}$ Kuśnierz, W świecie stalinowskich zbrodni, s. 342-343. 
Biohraficzni dowidky na mytropołytiw, jepyskopiw ta swiaszczennykiw UAPC, jaki zhadujut sia u dokumentach, ,Z Archiwiw WCzK-GPU-NKWD-KGB”, 1-2 (2006) s. 311-328.

Conquest Robert, Żnywa skorboty. Radiańska kołektywizacija i hołodomor, Kyjiw 1993

Dzwonkowski Roman SAC, Kościół katolicki w ZSSR 1917-1939. Zarys historii, Lublin 1997.

Dzwonkowski Roman SAC, Sowieckie państwo wyznaniowe, „Roczniki Nauk Społecznych", 1 (1997) s. 289-299.

Kornat Marek, Papież Pius XI i Polska w dobie totalitaryzmów i kryzysu systemu wersalskiego (1933-1939), „Studia nad Faszyzmem i Zbrodniami Hitlerowskimi”, 30 (2008)s. 162-226.

Kuśnierz Robert, Czystki i terror na Ukrainie (1934-1938), Toruń 2016.

Kuśnierz Robert, Ukraina w latach kolektywizacji i Wielkiego Głodu (1929-1933), Toruń 2005.

Kuśnierz Robert, W świecie stalinowskich zbrodni. Ukraina w latach czystek i terroru (1934-1938) w obserwacjach i analizach MSZ oraz wywiadu wojskowego Drugiej Rzeczypospolitej, Słupsk 2013.

Lityński Adam, Prawo Rosji i ZSRR 1917-1991 czyli historia wszechzwiązkowego komunistycznego prawa (bolszewików). Krótki kurs, Warszawa 2010.

Łoszyćkyj Ołeksandr, „Łaboratorija”. Nowi dokumenty i swidczennia pro masowi represiji 1937-1938 rokiw na Winnyczyni, „Z Archiwiw WUCzK-GPU-NKWD-KGB”, 1-2 (1998) s. 183-227.

Paszczenko Wołodymyr, Kyrydon Ałła, Bilszowyćka derżawa i prawosławna cerkwa w Ukrajini, 1917-1930-ti roky, Połtawa 2004.

Petrone Karen, Life Has Become More Joyous, Comrades: Celebrations in the Time of Stalin, Bloomington-Indianapolis 2000.

Rublowa Natalia, Represiji proty „cerkownykiw” i „sektantiw” w URSR, 1917-1939 rr., „Z Archiwiw WUCzK-GPU-NKWD-KGB”, 1 (2007) s. 205-219.

Tołczyk Dariusz, Gułag w oczach Zachodu, Warszawa 2009.

Wróbel Janusz, Polityka ZSRR wobec Kościoła katolickiego w latach 1917-1939, w: Polacy w Kościele katolickim w ZSRR, red. Edward Walewander, Lublin 1989, s. 85109.

Żyluk Serhij, Czerwonyj teror proty duchowenstwa i wirujuczych na Schidnij Wołyni (Żytomyrszczyna) u 20-30-ch rokach XX st. Archiwni dokumenty ta materiały, Riwne 2003.

\section{Prasa}

„Nowa Europa Wschodnia”, 2014.

„Prawda”, 1937.

\section{Netografia}

Konstitucija (osnownoj zakon) Sojuza Sowietskich Socialisticzieskich Riespublik. Utwierżdiena Czriezwyczajnym VIII zjezdom Sowietow Sojuza SSR 5 diekabria 1936 goda, http://www.hist.msu.ru/ER/Etext/cnst1936.htm, (dostęp: 06.06.2015). 


\title{
THE STALIN CONSTITUTION OF 1936 AND HOPES OF THE FAITHFUL LIVING IN THE SOVIET UKRAINE FOR A CHANGE OF THE ANTI-RELIGIOUS BOLSHEVIK POLICY
}

\begin{abstract}
Summary
This article discusses Ukrainians' hope for a change of the anti-religious Bolshevik policy after the adoption of the Stalin Constitution in 1936. Article 124 of the constitution encouraged the faithful to ask for reactivating closed churches, releasing arrested priests and allowing priests to conduct their duties. However, the constitution did not lead to any improvement in the life of the faithful. The Bolsheviks adopted,,the most democratic constitution in the world", but they interpreted liberties it contained in their own way.
\end{abstract}

Keywords: the Stalin Constitution; Soviet Ukraine; Stalinist repression 